\title{
Pelatihan Keterampilan Mengajar Di Pondok Pesantren Bahrul Maghfiroh Kota Malang
}

Siti Sumarsilah ${ }^{1}$, Susandi ${ }^{2}$, Anita Kurnia Rachman ${ }^{3^{*}}$

1,2,3IKIP Budi Utomo Malang

${ }^{*}$ Corresponding author

E-mail: anita27rachman@gmail.com (Anita Kurnia Rachman)*

Article History:

Received: $31-8-2020$

Revised: $17-9-2020$

Accepted: $17-9-2020$

Keywords:

\begin{abstract}
Keterampilan dasar mengajar merupakan keterampilan yang harus dimiliki guru untuk melaksanakan tugas mengajar secara profesional. Kegiatan pengabdian ini dilakukan oleh Dosen Prodi Pendidikan Bahasa dan Sastra Indonesia IKIP Budi Utomo Malang bekerja sama dengan Pondok Pesantren Bahrul Maghfiroh Malang. Kegiatan ini memberikan solusi bagi permasalahan yang dialami mitra. Solusi tersebut meliputi pelatihan keterampilan membuka pelajaran, keterampilan menutup pelajaran, keterampilan menjelaskan, keterampilan bertanya, keterampilan memberi penguatan, keterampilan mengadakan variasi, keterampilan membimbing diskusi kelompok, keterampilan mengajar kelompok kecil dan mengajar perseorangan, serta keterampilan mengelola kelas. Hasil kegiatan ini guru mampu menguasai sembilan keterampilan dasar mengajar. Kegiatan pelatihan keterampilan dasar mengajar dilaksanakan selama tiga hari dan memberikan pengalaman, pemahaman dan membantu para pengajar dalam mengoptimalkan peran di dalam kelas.
\end{abstract}

Pelatihan, Keterampilan, Mengajar 


\section{Pendahuluan}

Pondok Pesantren Bahrul Maghfiroh Malang merupakan salah pondok yang berdiri tahun 2018. Pondok Pesantren ini dipimpin oleh Prof. Dr. Ir. Mohammad Bisri, MS. Pondok ini memiliki yayasan pendidikan yang menaungi jenjang SD, SMP, dan SMA. Pondok pesantren ini terletak di Kecamatan Lowokwaru, Kota Malang, Jawa Timur. Secara geografis, Kecamatan Lowokwaru sebelah utara berbatasan dengan Kecamatan Karangploso, sebelah timur berbatasan dengan Kecamatan Blimbing, sebelah selatan berbatasan dengan Kecamatan Klojen, dan sebelah barat berbatasan dengan Kecamatan Dau. Wilayah kecamatan Lowokwaru dikelilingi dengan kampus baik kampus negeri, seperti Universitas Brawijaya, Universitas Negeri Malang, dan Universitas Islam Negeri. Kampus swasta yang ada di kecamatan Lowokwaru, yaitu Universitas Muhammadiyah Malang, Universitas Islam Malang, Institut Nasional Malang, STIE Malangkucecwara, dan STIEKMA.

Kegiatan analisis situasi dan diskusi dilakukan bersama mitra bertujuan untuk mengetahui kondisi dan permasalahan yang dihadapi mitra. Berdasarkan hasil kegiatan tersebut, dapat diketahui bahwa mitra memiliki permasalahan tentang keterampilan dasar mengajar guru, khususnya guru SMP di Pondok Pesantren Bahrul Maghfiroh Malang.

Guru memiliki peran penting dalam proses belajar mengajar di sekolah. Proses belajar mengajar merupakan interaksi antara peserta didik dan pendidik. Proses pembelajaran diharapkan dapat memberikan pelayanan maksimal kepada peserta didik untuk meningkatkan hasil belajarnya. Guru merupakan tenaga pendidik profesional yang berada dalam lingkungan pendidikan. Sutardi (2016) menyebutkan proses pembelajaran membutuhkan seorang guru yang merupakan tenaga profesional mengandung makna ahli dan bertanggung jawab atas kewajiban yang diembannya. Pendidikan merupakan salah satu sarana strategis bagi peningkatan mutu sumber daya manusia. Berdasarkan Undang-Undang Nomor 14 Tahun 2005 Tentang Guru dan Dosen, yaitu tugas utama seorang guru adalah mendidik, mengajar, membimbing, mengarahkan, melatih, menilai, dan mengevaluasi peserta didik pada pendidikan anak usia dini jalur pendidikan formal, pendidikan dasar, dan pendidikan menengah. Seorang guru harus memiliki empat kompetensi dasar, yaitu kompetensi pedagogik, kepribadian, sosial dan profesional.

Guru sebagai pengajar yang menyampaikan ilmu harus kreatif dalam menciptakan suasana belajar yang disukai peserta didik. Guru harus mengetahui suasana atau kondisi untuk melakukan pembelajaran agar semua informasi dan materi pembelajaran dapat ditangkap dan diterima peserta didik dengan baik. Keterampilan mengajar yang dimiliki oleh guru diharapkan dapat membuat peserta didik bersemangat untuk belajar dan memperhatikan penjelasan guru, serta dapat ikut aktif dalam proses pembelajaran sehingga hasil yang dicapai dari proses pembelajaran dapat memuaskan guru dan peserta didik (Kristiana dan Muhibbin, 2018). 
Kemampuan guru didukung dengan kompetensi pedagogik yang merupakan kemampuan guru dalam mengelola pembelajaran peserta didik dan menuntut guru untuk memiliki suatu keterampilan yang dapat membantunya dalam melaksanakan tugas tersebut. Hal ini seperti diungkapkan Mulyasa (2009: 60) keterampilan mengajar guru merupakan kompetensi pedagogik guru. Keterampilan guru dikenal dengan istilah keterampilan dasar mengajar (general teaching skills). Keterampilan merupakan kemampuan atau kompetensi yang dimiliki. Sedangkan keterampilan dasar mengajar merupakan suatu karakteristik umum dari seseorang yang berhubungan dengan pengetahuan dan keterampilan yang diwujudkan melalui tindakan. Daryanto \& Farid (2015) menyebutkan bahwa kompetensi yang harus dimiliki guru yang menjadi komponen penting dalam pendidikan ialah kompetensi pedagogik, kompetensi kepribadian, kompetensi profesional dan kompetensi sosial. Keempat kompetensi ini haruslah tercermin dalam diri seorang pendidik yang diimplementasikan dalam pembelajaran di sekolah. Dilihat dari cara berinteraksi dengan orang lain, sikap-sikap yang patut diteladani dan mampu menguasai materi serta menyampaikannya dengan cara yang tepat dan disesuaikan dengan potensi sekolah. Kemampuan tersebut termasuk ke dalam keterampilan guru dalam mengajar (Jupriyanto dan Nuridin, 2019). Hal ini dipertegas oleh pernyataan Setiani dan Donni, 2015: 18 (dalam Kristiana dan Muhibbin, 2018) bahwa guru yang paripurna adalah guru yang menguasai keterampilan dasar mengajar secara baik.

Keterampilan dasar mengajar pada dasarnya berupa bentuk-bentuk perilaku yang bersifat mendasar dan khusus yang harus dimiliki oleh seorang guru sebagai modal awal untuk melaksanakan tugas-tugas mengajarnya secara terencana dan profesional. Uno (2010:33) menyebutkan keterampilan mengajar merupakan kemampuan atau kecakapan guru dalam membimbing aktivitas belajar. Sedangkan Sundari (2014) menyebutkan bahwa keterampilan mengajar ialah kecakapan guru dalam menyajikan materi pelajaran antara lain, menguasai bahan pengajaran mampu memilih metode yang tepat dan penguasaan kelas dengan baik. Keterampilan tersebut tercermin dalam proses pembelajaran guru bertanya, membuka menutup pembelajaran, dan cara dalam menyampaikan materi pembelajaran.

Kusnadi (2008) menyebutkan bahwa seorang guru yang memiliki kemampuan keterampilan mengajar dalam melakukan pengajaran kepada peserta didik agar dapat memahami pelajaran yang akan diajarkan. Oleh karena itu guru harus terampil dan selalu mempunyai trik untuk dapat membuat suasana menjadi lebih menyenangkan sehingga aktivitas peserta didik tidak membosankan. Karwati dan Donni, 2014: 80-88 (dalam Kristiana dan Muhibbin, 2018) menyebutkan komponen keterampilan dasar mengajar guru meliputi: keterampilan bertanya, keterampilan memberi penguatan, kekuatan mengadakan variasi, keterampilan menjelaskan, keterampilan membuka dan menutup pembelajaran, keterampilan membimbing diskusi kelompok kecil, keterampilan mengelola kelas, dan keterampilan mengajar perorangan. Menurut Adediwura \& Tayo, 2007 (dalam Safitri dan Sontani, 2016) 
menyatakan tidak ada yang bisa mengajarkan sesuatu kepada seseorang tanpa melakukannya dalam beberapa cara tertentu maka dari itu cara mengajar memiliki pengaruh yang signifikan terhadap seluruh situasi pada proses belajar mengajar. Keterampilan mengajar dapat ditanamkan melalui program pendidikan guru yang efektif. Keterampilan mengajar yang dikemukakan oleh Allen dan Ryan di Stanford University Amerika (dalam Safitri dan Sontani, 2016), yaitu (1) stimulus variasi; (2) set induksi; (3) penutupan; (4) guru berdiam diri dan menggunakan non-verbal isyarat; (5) memperkuat partisipasi murid; (6) kelancaran dalam bertanya; (7) menggali pertanyaan; (8) gunakan pertanyaan yang lebih susah; (9) pertanyaan yang divergen; (10) mengakui dan menghadiri perilaku; (11) ilustrasi dan penggunaan contoh; (12) Ceramah; (13) pengulangan rencana; dan (14) ketuntasan komunikasi.

Keterampilan dasar mengajar berkenaan dengan beberapa keterampilan yang bersifat mendasar dan melekat yang harus dimiliki dan diaktualisasikan oleh setiap guru (Achdiani dan Rusliyani, 2017). Menurut Turney (dalam Mulyasa, 2013: 60) menyebutkan sembilan keterampilan dasar mengajar yang sangat berperan dan menentukan kualitas pembelajaran, keterampilan tersebut, yaitu (1) keterampilan membuka pelajaran; (2) menutup pelajaran; (3) bertanya; (4) memberi penguatan; (5) mengadakan variasi; (6) menjelaskan; (7) membimbing diskusi kelompok kecil; (8) mengajar kelompok kecil dan mengajar perseorangan, serta; (9) mengelola kelas.

Kegiatan memberikan keterampilan dasar mengajar juga pernah dilakukan, namun dalam bentuk penelitian. Kegiatan yang pernah dilakukan, yaitu penelitian oleh Siswanto tahun 2010 dengan judul Tingkat Penguasaan Keterampilan Dasar Mengajar Mahasiswa Prodi Pendidikan Akuntansi Fakultas IImu Sosial dan Ekonomi Universitas Negeri Yogyakarta. Penelitian ini diterbitkan pada Jurnal Pendidikan Akuntansi Indonesia. Vol. VIII. No. 2 Tahun 2010, hal. 41 - 51. Penelitian lainnya dilakukan oleh Sundari dan Muliyawati tahun 2017 dengan judul Analisis Keterampilan Dasar Mengajar Mahasiswa PGSD dan telah diterbitkan pada PEDAGONAL: Jurnal Ilmiah Pendidikan. Vol 1 No 1 tahun 2017, hal. 26-36. Penelitian selanjutnya juga pernah dilakukan oleh Nurlaili tahun 2018 dengan judul Analisis Keterampilan Dasar Mengajar Guru Dalam Perspektif Guru Pamong Pada Mahasiswa Prodi PGMI Fakultas IImu Tarbiyah dan Keguruan UIN Raden Fatah Palembang yang diterbitkan pada Jurnal IImiah PGMI. Vol 4, No 1, Juni 2018.

Berdasarkan hasil diskusi, maka pengabdian ini memiliki tujuan, yaitu 1) Memberikan solusi bagi guru yang kurang mampu dalam keterampilan membuka pelajaran; 2) Memberikan solusi bagi guru yang kurang mampu dalam keterampilan menutup pelajaran; 3) Memberikan solusi bagi guru yang kurang mampu dalam keterampilan menjelaskan; 4) Memberikan solusi bagi guru yang kurang mampu dalam keterampilan bertanya; 5) Memberikan solusi bagi guru yang kurang mampu dalam keterampilan memberi penguatan; 6) Memberikan solusi bagi guru yang kurang mampu dalam keterampilan mengadakan variasi; 7) Memberikan solusi bagi 
guru yang kurang mampu dalam keterampilan membimbing diskusi kelompok kecil; 8) Memberikan solusi bagi guru yang kurang mampu dalam keterampilan mengajar kelompok kecil dan mengajar perseorangan; 9) Memberikan solusi bagi guru yang kurang mampu dalam mengelola kelas.

Kegiatan pengabdian ini diharapkan dapat memberikan manfaat berupa informasi keterampilan mengajar guru. Dengan mengetahui manfaat dari keterampilan mengajar guru nantinya dapat menginspirasi guru untuk lebih meningkatkan keterampilannya dalam mengajar untuk menciptakan suasana belajar yang menyenangkan dan tidak membosankan.

\section{Metode}

Pelaksanaan program pengabdian masyarakat dilaksanakan di lokasi mitra, yakni Pondok Pesantren Bahrul Maghfiroh. Tahapan yang dilakukan, yaitu meminta izin kepada Kepala Sekolah, yaitu Bapak KH. Abdul Aziz S. Faqih dan melakukan diskusi tentang permasalahan yang dihadapi.

Tahapan pelaksanaan Pengabdian Masyarakat adalah sebagai berikut: 1) Diskusi rencana kerja, yaitu perencanaan tentang agenda kegiatan yang dilaksanakan selama tiga hari, yaitu tanggal 10-12 April 2020; 2) Pelatihan kegiatan, yaitu pemberian materi teori dan praktek, dengan komposisi $30 \%$ teori dan $70 \%$ praktek, Pemberian teori dilaksanakan pada tanggal 10 April 2020; 3) Kegiatan praktek mengajar dilaksanakan pada tanggal 11-12 April 2020, Kegiatan ini dilakukan dengan bimbingan dari pemateri; 4) Kegiatan refleksi pembelajaran dilakukan pada tanggal 12 April 2020; 5) Evaluasi dan Monitoring program secara keseluruhan untuk memberikan solusi terhadap permasalahan yang timbul selama kegiatan dan kesiapan para guru setelah kegiatan Pengabdian Masyarakat berakhir.

\section{Hasil}

Berdasarkan hasil kegiatan pelatihan di Pondok Pesantren Bahrul Maghfiroh Malang, maka dapat disimpulkan sebagai berikut:

1) Keterampilan guru dalam membuka pelajaran - Kegiatan membuka pelajaran merupakan keterampilan yang harus dikuasai guru. Keterampilan ini akan memberikan motivasi kepada peserta didik untuk mengikuti pembelajaran dengan semangat. Guru SMP di Pondok Bahrul Maghfiroh mayoritas telah mampu membuka pelajaran dengan baik. Guru perlu memahami bahwa menghubungkan materi yang telah dikuasai peserta didik dengan materi yang akan disampaikan, sebagai titik tolak dalam memulai kegiatan pembelajaran yang baru. Achdiani dan Rusliyani (2017) menyatakan bahwa penguasaan keterampilan membuka pelajaran akan menentukan termotivasi atau tidaknya siswa dalam mengikuti kegiatan pembelajaran. Siswa yang memiliki motivasi belajar tinggi akan mendorong perhatiannya terpusat pada topik-topik yang harus dipelajari, sehingga dapat mencapai tujuan pembelajaran secara 
maksimal. Mansyur (2017) menyatakan inti persoalan membuka pelajaran terkait dengan usaha guru dalam menarik perhatian siswa, memotivasi, memberi acuan tentang rujukan, pokok persoalan yang akan dibahas, rencana kerja serta pembagian waktu, dan mengaitkan pelajaran yang telah dipelajari dengan topik baru. Menyiapkan mental siswa untuk siap memasuki persoalan yang akan dibicarakan, dan membangkitkan minat dan perhatian siswa yang akan dibicarakan dalam kegiatan belajar mengajar.

2) Keterampilan guru dalam menutup pelajaran - Guru SMP di Pondok Bahrul Maghfiroh sebagian besar memiliki keterampilan menutup pelajaran dengan baik karena sebagian besar mampu melakukannya, yaitu dapat mencuri perhatian peserta didik dengan menampilkan gaya mengajar guru yang bervariasi, menggunakan alat bantu dan mampu membuat suasana belajar yang bervariasi, dan pola interaksi yang dinamis serta antusias belajar peserta didik yang baik, sehingga menimbulkan keingintahuan yang tinggi pada peserta didik selain itu peserta didik dapat mengikuti langkah-langkah pembelajaran yang sesuai prosedur. Kegiatan menutup pelajaran merupakan kegiatan yang dilakukan oleh guru untuk mengakhiri pelajaran dengan mengemukakan kembali pokok-pokok pelajaran yang bertujuan untuk memberikan gambaran menyeluruh tentang apa yang telah dipelajari, mengetahui keberhasilan peserta didik dalam menyerap pelajaran, dan menentukan titik pangkal untuk pelajaran berikutnya. Asril (2011:71) menyebutkan inti kegiatan menutup pelajaran, yaitu (1) merangkum atau meringkas inti pokok pelajaran; (2) mengonsolidasikan perhatian peserta didik pada masalah pokok pembahasan agar informasi yang diterimanya dapat membangkitkan minat dan kemampuannya terhadap pelajaran selanjutnya; (3) mengorganisasikan semua pelajaran yang telah dipelajari sehingga memerlukan kebutuhan yang berarti dalam memahami materi pelajaran, (4) memberikan tindak lanjut berupa saran-saran serta ajakan agar materi yang baru dipelajari.

3) Keterampilan guru dalam menjelaskan - Berdasarkan hasil pelatihan, guru SMP di Pondok Bahrul Maghfiroh telah mampu menjelaskan dengan baik dan jelas dalam memotivasi peserta didik. Pada aspek bahasa, guru sudah menggunakan susunan kalimat yang mudah dipahami peserta didik. Guru telah menggunakan contoh dalam penyampaian materi pelajaran, namun memberikan motivasi dan tekanan suara atau gambar masih perlu latihan. Beberapa guru dalam menjelaskan sudah dapat mengembangkan materi yang disampaikan dan ada yang masih membaca teks, meskipun sudah dibantu dengan media pembelajaran. Menjelaskan pada dasarnya menuturkan secara lisan mengenai suatu bahan pelajaran. Pentingnya keterampilan menjelaskan dikuasai oleh guru, karena tidak semua siswa dapat menggali sendiri pengetahuan dari buku atau dari sumber lainnya (Mansyur, 2017). Alma (2012:21) menyatakan bahwa keterampilan 
menjelaskan berhubungan dengan: a) penyampaian sesuatu ide/pendapat atau pemikiran (dalam hal ini bahan pelajaran) dalam bentuk kata-kata; b) pengorganisasian dalam menyampaikan ide tersebut yang meliputi sistematika penyampaian dan hubungan antar hal yang terkandung dalam ide itu; c) upaya untuk secara sadar menumbuhkan pengertian ataupun pemahaman pada diri siswa.

4) Keterampilan guru dalam bertanya - Bertanya merupakan salah satu aktivitas yang selalu ada dalam proses komunikasi, memberi stimulus kepada siswa dalam bentuk kalimat tanya yang membutuhkan jawaban (Nurlaili, 2018). Keterampilan bertanya yang dimiliki guru sudah cukup baik dan guru telah berusaha dengan baik agar pertanyaan-pertanyaan yang diberikan kepada peserta didik dapat memotivasi peserta didik untuk terlibat aktif dalam interaksi belajar mengajar di kelas. Usman (2013:75) memberikan dasar-dasar pertanyaan yang baik, yaitu a) jelas dan mudah dimengerti oleh siswa; b) berikan informasi yang cukup untuk menjawab pertanyaan siswa; c) difokuskan pada suatu masalah atau tugas tertentu; d) berikan waktu yang cukup kepada anak untuk berpikir sebelum menjawab pertanyaan; e) bagikanlah semua pertanyaan kepada seluruh murid secara merata; f) berikanlah respons yang ramah dan menyenangkan sehingga timbul keberanian siswa untuk menjawab atau bertanya, dan; g) tuntunlah jawaban siswa sehingga mereka dapat menemukan sendiri jawaban yang benar. Hasil pelatihan memberikan manfaat kepada guru karena guru dapat melaksanakan keterampilan bertanya dengan baik, dapat memberikan penjelasan materi dan dapat disampaikan dengan baik kepada peserta didik.

5) Keterampilan guru dalam memberi penguatan - Penguatan adalah tanggapan guru terhadap perilaku siswa yang memungkinkan dapat membesarkan hati siswa agar lebih terpacu dalam interaksi pembelajaran (Nurlaili, 2018). Penguatan merupakan respon positif yang dilakukan guru terhadap suatu perilaku peserta didik yang dapat meningkatkan kemungkinan terulangnya kembali perilaku tersebut. Siswanto (2010) menyatakan bahwa penguatan adalah tanggapan guru terhadap perilaku siswa yang memungkinkan dapat membesarkan hati siswa agar lebih terpacu dalam interaksi belajar-mengajar. Asril (2011: 79) membagi keterampilan penguatan dapat dikelompokkan kepada dua jenis, yaitu penguatan verbal dan penguatan non-verbal. a) Penguatan verbal, diungkapkan atau diutarakan dengan menggunakan kata-kata, pujian, penghargaan, persetujuan dan sebagainya, misalnya; bagus sekali, betul, pintar, saya senang dan sebagainya; b) Penguatan non-verbal, berupa mimik dan gerakan tubuh. Berupa mimik dan gerakan tangan dengan pendekatan, dan menggunakan sentuhan digosok-gosok punggungnya. Menggunakan simbol atau benda, seperti anak disuruh mengerjakan PR di papan tulis, kemudian diberikan tanda betul. Berdasarkan hasil pelatihan dapat disimpulkan bahwa guru SMP di Pondok Bahrul 
Maghfiroh telah mampu memberikan penguatan dengan berbagai variasi. Variasi yang dilakukan guru seperti ucapan pujian "ya bagus nak, jawabanmu benar". Selain itu, ada yang berupa simbol mengacungkan jempol, mimik wajah yang menunjukan keantusiasan, dan lain sebagainya.

6) Kemampuan guru dalam mengadakan variasi - "Pemberian variasi dalam interaksi belajar mengajar diartikan sebagai perubahan pengajaran dari yang satu ke yang lain dengan tujuan untuk menghilangkan kebosanan dan kejenuhan siswa dalam menerima bahan pengajaran yang diberikan guru, sehingga siswa dapat aktif lagi dan berpartisipasi dalam belajarnya (Sutomo,1993:101 dalam Nurlaili, 2018). Penggunaan variasi mengajar yang dilakukan guru bertujuan untuk mengurangi kejenuhan yang dialami peserta didik dalam proses pembelajaran, sehingga dalam proses pembelajaran tersebut, peserta didik senantiasa menunjukkan ketekunan, antusiasme, serta penuh partisipasi. Penggunaan variasi oleh guru SMP di Pondok Pesantren Bahrul Maghfiroh sudah cukup baik. Keterampilan variasi meliputi variasi suara, mengarahkan perhatian peserta didik, variasi dalam proses belajar mengajar, dan sebagainya. Sanjaya (2006: 166) menjelaskan keterampilan dasar variasi adalah keterampilan guru untuk menjaga agar iklim pembelajaran tetap menarik perhatian, tidak membosankan, sehingga siswa menunjukkan sikap antusias dan ketekunan, penuh gairah berpartisipasi aktif dalam setiap langkah kegiatan pembelajaran. Usman (2013:85-87) membagi keterampilan mengadakan variasi ada tiga macam, yaitu variasi cara mengajar guru, variasi dalam menggunakan media atau alat pengajaran, dan Variasi pola interaksi dan kegiatan siswa.

7) Variasi cara mengajar guru, misalnya 1) Penggunaan variasi, yaitu: suara dari keras menjadi lembut, dari tinggi menjadi rendah, dan dari cepat menjadi lambat. 2) Pemusatan perhatian misalnya, perhatikan baik-baik!, jangan ribut! dan lain-lain. 3) Kesenyapan atau kebisuan, pada saat menjelaskan tiba-tiba guru diam sejenak untuk menarik perhatian. 4) Mengadakan kontak pandang yaitu menjelajah seluruh kelas dan melihat mata seluruh peserta didik. 5) Gerakan kepala dan ekspresi wajah seperti mengangguk, menggeleng, tersenyum, menaikkan alis mata dan sebagainya. 6) Pergantian posisi dan gerak di dalam kelas, agar bisa bisa mengontrol tingkah laku siswa. Variasi dalam menggunakan media dan alat pengajaran, misalnya. 1) Variasi alat atau bahan yang dapat dilihat (visual aids), misalnya grafik, bagan, poster, gambar film dan slide. 2) Variasi alat atau bahan yang dapat didengar (auditif aids), misalnya rekaman suara, suara radio, musik deklamasi puisi, dan sosiodrama. 3) Variasi alat atau bahan yang dapat diraba, dan digerakkan (motorik), misalnya peragaan siswa, model, spesimen, patung, topeng dan boneka. 4) Variasi alat atau bahan yang dapat didengar, dilihat dan diraba (audio-visual aids), misalnya film, televisi, radio, slide proyektor yang diiringi penjelasan guru. Variasi pola interaksi dan kegiatan siswa, bertujuan agar 
tidak menimbulkan kebosanan dan kejenuhan siswa serta menghidupkan suasana kelas kondusif. Adapun jenis pola interaksi ada lima pola, yaitu:

a) Pola guru-murid, yaitu komunikasi sebagai aksi satu arah;

b) Pola guru-murid-guru, yaitu ada balikan (feedback) bagi guru, tidak ada interaksi antar siswa;

c) Pola guru-murid-murid, yaitu ada balikan bagi guru, siswa saling belajar satu sama lain;

d) Pola guru-murid, murid-guru, murid-murid, yaitu interaksi optimal antara guru dengan murid dan antara murid dengan guru (komunikasi multi arah);

e) Pola melingkar yaitu setiap siswa mendapat giliran untuk mengemukakan sambutan atau jawaban, tidak diperkenankan berbicara dua kali apabila setiap siswa mendapat giliran.

8) Keterampilan guru dalam membimbing diskusi kelompok kecil

Keterampilan membimbing diskusi kelompok kecil perlu dikuasai oleh guru, sebab diskusi memungkinkan siswa untuk menguasai konsep-konsep materi untuk memecahkan suatu masalah melalui proses berpikir kritis, percaya diri, berani berpendapat secara kritis dan positif serta mampu berinteraksi dengan teman dan lingkungan sosialnya. Achdiani dan Rusliyani (2017) menyatakan bahwa penguasaan keterampilan membimbing diskusi kecil menuntut guru untuk dapat mengarahkan diskusi agar tetap menuju pada masalah yang dibahas serta terampil dalam mendengarkan dan merumuskan hasil-hasil diskusi sehingga dapat memotivasi peserta didik untuk berpartisipasi dalam seluruh kegiatan diskusi. Berdasarkan hasil kegiatan pelatihan yang dilakukan, guru SMP di pondok Bahrul Maghfiroh mayoritas telah mampu membimbing diskusi kelompok kecil. Beberapa masih perlu latihan ketelatenan dan kesabaran dalam membimbing peserta didik dalam kegiatan diskusi kelompok kecil tersebut. Mansyur (2017) menyebutkan bahwa peserta didik berdiskusi dalam kelompok-kelompok kecil di bawah pimpinan guru atau temannya untuk berbagai informasi, pemecahan masalah, atau pengambilan keputusan tersebut berlangsung dalam suasana terbuka. Setiap siswa bebas mengemukakan ide-idenya tanpa merasa ada tekanan dari teman atau gurunya, dan setiap peserta didik harus mentaati peraturan yang ditetapkan sebelumnya.

9) Keterampilan guru dalam mengelola kelas

Suatu kondisi belajar yang baik akan tercapai jika guru mampu mengatur peserta didik dan sarana pengajaran serta mengendalikannya dalam suasana yang menyenangkan untuk mencapai tujuan pengajaran. Alma (2012: 81) menyatakan bahwa suatu kondisi belajar yang baik akan tercapai jika guru mampu mengatur siswa dan sarana pengajaran serta mengendalikannya dalam suasana yang menyenangkan untuk mencapai tujuan pengajaran.

Berdasarkan hasil pelatihan, guru cukup mampu dalam mengelola kelas. 
Namun, guru harus lebih belajar lagi tentang keterampilan dalam mengelola kelas agar kegiatan belajar mengajar lebih baik lagi. Prinsip-prinsip pengelolaan kelas merupakan pegangan atau acuan yang pengetahuan mengenai prinsip pengelolaan kelas perlu dimiliki dan dikuasai mahasiswa, salah satunya yaitu prinsip penekanan pada nilai-nilai yang positif. Pada dasarnya dalam mengajar dan mendidik, guru harus menekankan pada hal-hal yang positif dan menghindari pemusatan perhatian anak didik pada hal-hal yang negatif. Prinsip ini digunakan dalam rangka memperkecil masalah gangguan dalam kegiatan pembelajaran (Achdiani dan Rusliyani, 2017).

Hasil yang telah dicapai dalam program pengabdian kepada masyarakat sebagai berikut.

1) Kegiatan 1 - Survey dan Diskusi Rencana Kegiatan - Kegiatan pengabdian ini dimulai dengan survey awal dan diskusi rencana kegiatan. Diskusi rencana kegiatan dilaksanakan pada hari Senin, 2 Maret 2020. Kegiatan dilaksanakan selama satu hari yang bertempat di Pondok Pesantren Bahrul Maghfiroh Kota Malang. Pada diskusi rencana kegiatan ini melibatkan beberapa guru SMP untuk bertanya langsung tentang permasalahan yang muncul. Pada kegiatan ini juga disusun rencana kegiatan untuk pengabdian yang akan dilaksanakan selama tiga hari dan telah disepakati oleh pihak pondok pesantren.

2) Kegiatan 2 - Pemberian Bantuan Masker dan Hand Sanitizer - Pemberian bantuan masker dan hand sanitizer ini diberikan sebagai bentuk rasa kepedulian dan wujud dukungan program pemerintah dalam mencegah penyebaran covid-19. Pemberian bantuan masker dan hand sanitizer ini dilakukan oleh tim pengabdian dari Prodi Pendidikan Bahasa dan Sastra Indonesia IKIP Budi Utomo Malang kepada Kepala Pondok Pesantren Bahrul Maghfiroh Malang. Pemberian bantuan ini diberikan pada tanggal 10 April 2020.

3) Kegiatan 3 - Pemberian Materi tentang Keterampilan Dasar Mengajar Kegiatan ini dilaksanakan untuk mengajak para guru untuk lebih memahami dasar-dasar mengajar yang meliputi kemampuan membuka pelajaran, menutup pelajaran, kemampuan bertanya, kemampuan menjelaskan, kemampuan memberikan penguatan, kemampuan memberikan variasi, kemampuan membimbing diskusi, dan kemampuan mengelola kelas. 


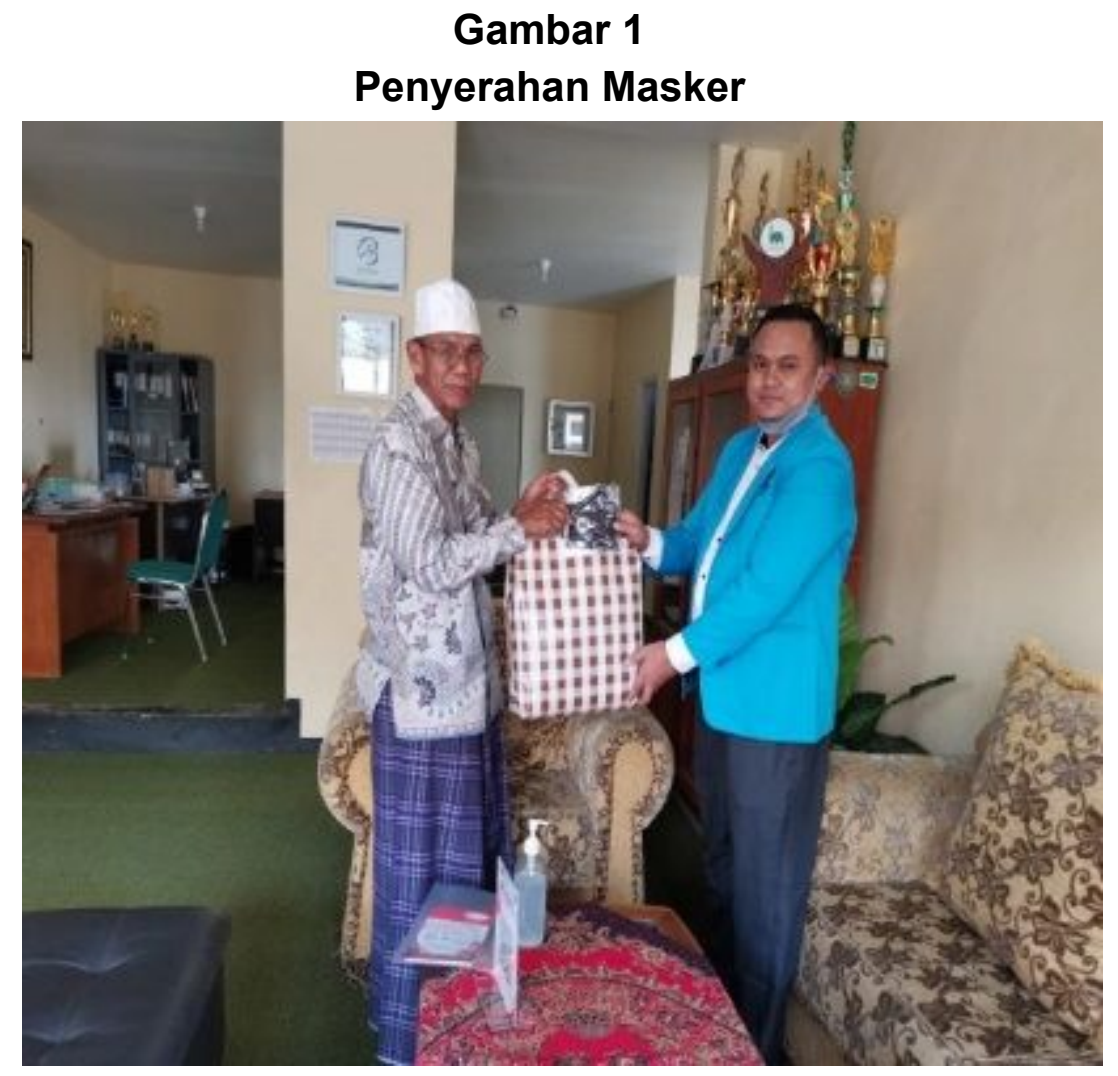

Gambar 2

Penyerahan Hand Sanitizer

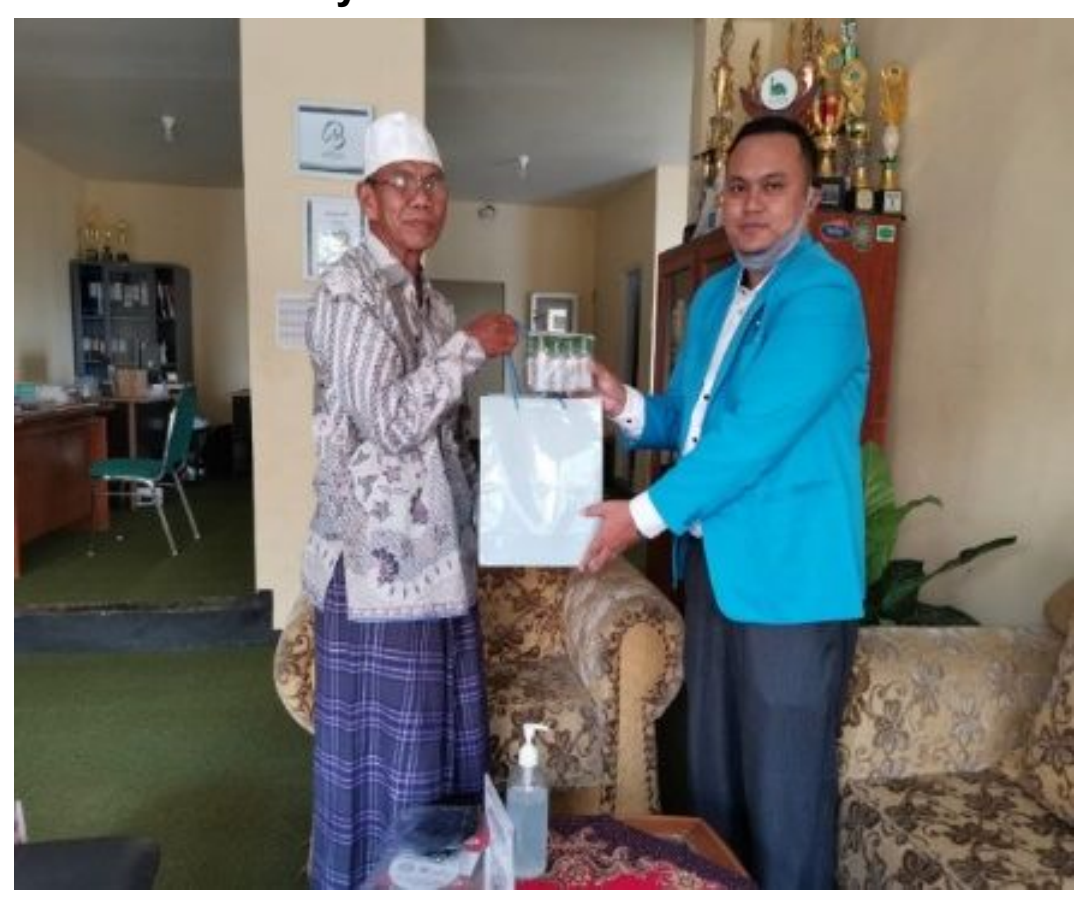



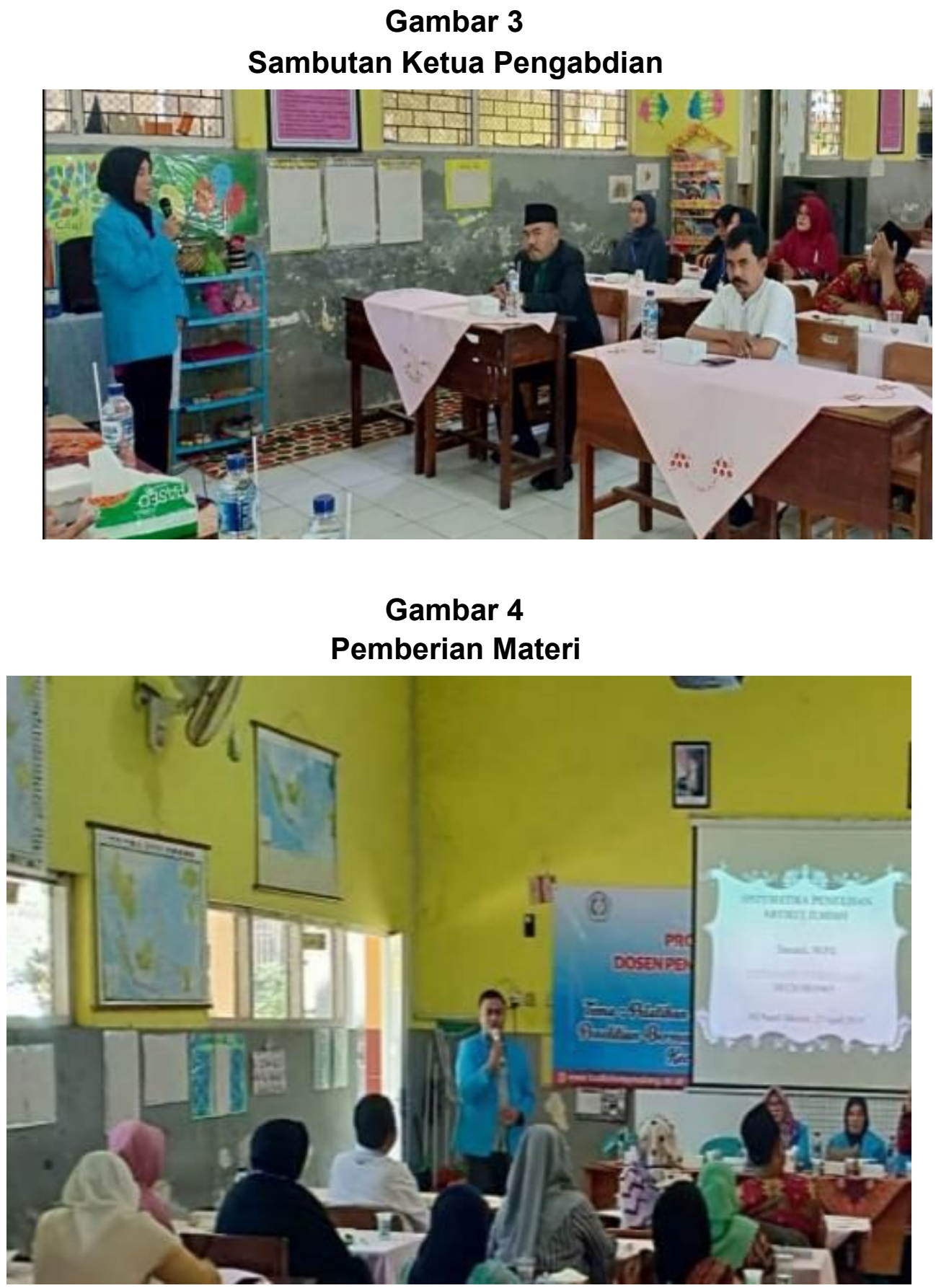


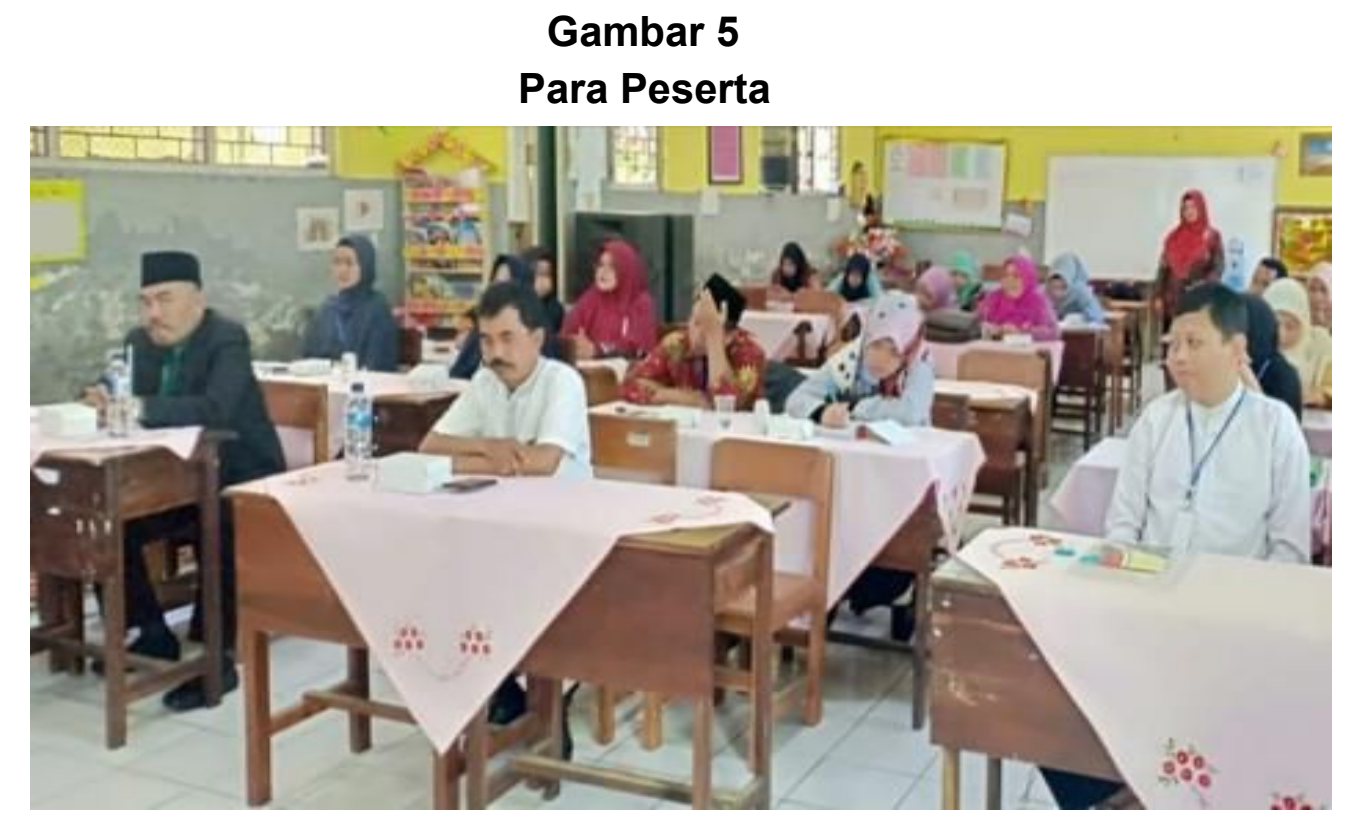

\section{Gambar 6}

Pemateri (Tim Pengabdian)

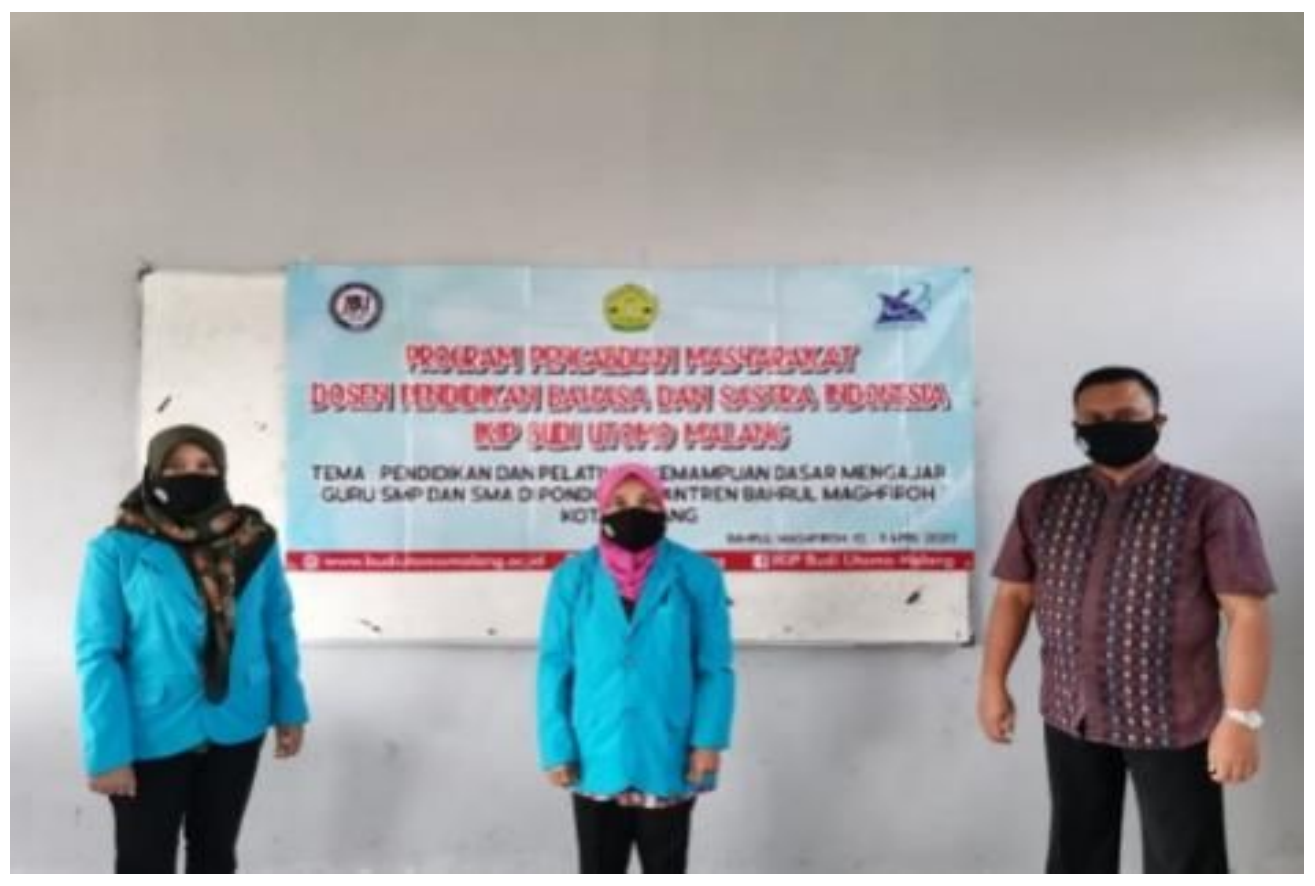




\section{Kesimpulan}

Kegiatan Pengabdian Masyarakat Program Pendidikan Masyarakat memiliki kesimpulan sebagai berikut. Guru dalam melaksanakan pembelajaran harus memiliki kemampuan dasar mengajar yang meliputi, kemampuan membuka pelajaran, menutup pelajaran, kemampuan bertanya, kemampuan menjelaskan, kemampuan memberikan penguatan, kemampuan memberikan variasi, kemampuan membimbing diskusi, dan kemampuan mengelola kelas. Kemampuan guru dalam mengajar akan memberikan semangat dan motivasi pada peserta didik. Terlebih jika pengajar mampu mengelola kelas dengan baik dan memberikan pembelajaran yang aktif dan kreatif.

\section{Daftar Referensi}

Achdiani, Yani dan Rusliyani, Dwi Ayu. (2017). Pengetahuan Keterampilan Dasar Mengajar dalam Menyiapkan Guru Sekolah Menengah Kejuruan, Jurnal TEKNOBUGA, vol. 5 no. 2 , pp. hal 34 - hal 43 . DOI: https://doi.org/10.1529/jtbb.v5i2.15368

Alma, et al., (2012) Guru Profesional Menguasai Metode dan Terampil Mengajar. Bandung: Alfabeta.

Asril, Zainal. (2011). Micro Teaching: Disertai dengan Program Pengalaman Lapangan. Jakarta: Rajawali.

Daryanto, \& Farid, M. (2015). Konsep Dasar Manajemen Pendidikan di Sekolah. Yogyakarta: Gava Media.

Jupriyanto dan Nuridin. (2019). Pengaruh Keterampilan Mengajar Guru terhadap Aktivitas Belajar Siswa SD Negeri 04 Lonin. Jurnal Pendidikan Dasar Indonesia. Vol. 4, No. 1. Maret 2019. Hal. 14 - 18. DOI: http://dx.doi.org/10.26737/jpdi.v4i1.944

Kristiana, Dini dan Muhibbin, A. (2018). Keterampilan Dasar Mengajar dalam Pembelajaran Matematika D SMP. Jurnal Managemen Pendidikan. Vol. 13, No. 2, Desember 2018: 204-209. DOI: https://doi.org/10.33751/jmp.v8i1

Kusnadi. (2008). Strategi Pembelajaran IImu Pengetahuan. Pekanbaru: Yayasan Pusaka Riau.

Mansyur. (2017). Keterampilan Dasar Mengajar dan Penguasaan Kompetensi (Suatu Proses Pembelajaran Micro). Jurnal el-Ghiroh, vol.12, no. 01, pp. hal 130-147. DOI: https://doi.org/10.37092/el-ghiroh.v12i1.31

Mulyasa. (2009). Menjadi Guru Professional. Bandung: Rosdakarya.

Mulyasa. (2013). Menjadi Guru Profesional Menciptakan Pembelajaran Kreatif dan Menyenangkan. Bandung: PT Remaja Rosdakarya.

Nurlaili, (2018). Analisis Keterampilan Dasar Mengajar Guru Dalam Perspektif Guru Pamong Pada Mahasiswa Prodi PGMI Fakultas IImu Tarbiyah dan Keguruan UIN Raden Fatah Palembang. Jurnal IImiah PGMI. Vol. 4, No 1, Juni 2018. DOI https://doi.org/10.19109/jip.v4i1.2270

Safitri, Eka dan Sontani, Uep Tatang. (2016). Keterampilan mengajar guru dan 
motivasi belajar siswa sebagai determinan terhadap hasil belajar. Jurnal Pendidikan Manajemen Perkantoran. Vol. 1 No. 1, Agustus 2016, hal. 144-153 DOI: https://doi.org/10.17509/jpm.v1i1.3258

Sanjaya, Wina. (2006). Pembelajaran dalam Implementasi Kurikulum Berbasis Kompetensi. Jakarta: Kencana.

Siswanto. (2010). Tingkat Penguasaan Keterampilan Dasar Mengajar Mahasiswa Prodi Pendidikan Akuntansi Fakultas IImu Sosial dan Ekonomi Fakultas IImu Sosial dan Ekonomi Universitas Negeri Yogyakarta, Jurnal Pendidikan Akuntansi Indonesia, vol. VIII. no. 2, pp. hal 41 - hal 51. DOI: https://doi.org/10.21831/jpai.v8i2.953.

Sundari, N. (2014). Optimalisasi Peningkatan Keterampilan Mengajar Mahasiswa dengan Menarapkan Model Berbasis Masalah dalam Pembelajaran IPS di SD. Edu Humaniora Jurnal Pendidikan Dasar. Vol. 6, No. 2. Hal. 125-135. DOI: https://doi.org/10.17509/eh.v6i2.4577

Sundari, Fitri Siti dan Muliyawati, Yuli. (2017). Analisis Keterampilan Dasar Mengajar Mahasiswa PGSD. PEDAGONAL Jurnal Ilmiah Pendidikan. Vol. 1 No. 1. Tahun 2017. Hal. 26-36. DOI: 10.33751/pedagog.v1i1.225

Sutardi, S. (2016). Pengaruh Kompetensi Guru, Motivasi Belajar, dan Lingkungan Keluarga terhadap Hasil Belajar Mata Pelajaran Ekonomi. Jurnal Pendidikan IPS , 3 (2), 188-189. DOI: https://doi.org/10.21831/hsjpi.v3i2.8400

Uno, H. B. (2010). Orientasi Baru dalam Psikologi Pembelajaran. Jakarta: Bumi Aksara.

Usman, U. (2013). Menjadi Guru Profesional. Bandung: PT. Remaja Rosdakarya. 